\title{
The changing position of housing estate neighbourhoods in the Helsinki metropolitan area
}

\author{
Johanna Lilius $^{1}$ (D) . Jukka Hirvonen ${ }^{2}$
}

Received: 17 April 2020 / Accepted: 4 August 2021

(c) The Author(s) 2021

\begin{abstract}
This paper addresses the under-researched phenomena of investments in the private rental markets in disadvantaged suburbs in Finland. Despite the application of a social-mixing policy in the Helsinki Metropolitan Area and the Nordic welfare model, suburban housing estate neighbourhoods built in the 1960s and 1970s have experienced a socioeconomic decline since the 1990s. According to several recent large surveys, housing estate neighbourhoods represent the least popular housing environments among Finns. Nevertheless, as the Helsinki Metropolitan Area is currently facing rapid population growth, these neighbourhoods have now become the target for heavy infill development, and ambitious city-led regeneration plans. Simultaneously, housing investment has become an opportunity in Finland for both national and, increasingly, also international real-estate investment companies, as well as for private households. We explore the resurge to invest in housing estate neighbourhoods through two case studies in the Helsinki Metropolitan Area. Using statistics and interviews with policymakers and institutional real-estate investors, as well as a review of policy documents as our data, we show the variegated ways in which the marketization and financialization of housing and urban renewal policies change the social geography of housing estates in the Helsinki Metropolitan Area.
\end{abstract}

Keywords Housing policy $\cdot$ Helsinki metropolitan area $\cdot$ Segregation $\cdot$ Real-estate investment $\cdot$ Social mix $\cdot$ Financialization

\section{Introduction}

Kontula is highly desired, somehow, you'd think 'c'mon-Kontula', but we have a lot of apartments there, new apartments, and we are developing more because they are so sought after, so clearly much better than its reputation... (Investor A).

Johanna Lilius

johanna.lilius@aalto.fi

Jukka Hirvonen

jukkahirvonen4@gmail.com

1 Department of Architecture, Aalto University, AALTO, P.O. Box 31000, 76000 Espoo, Finland

2 Urban Research and Statistics, P.O. Box 5500, 00099 City of Helsinki, Finland 
The above citation illustrates the view of one of the largest residential real-estate investment companies in Finland on what has been characterized as the most stigmatized housing estate neighbourhood in Finland. As the citation implies, the notion of the real-estate company is in stark contrast to recent studies carried out on the housing preferences of Finns. According to the residents' barometer conducted every fourth year by the Finnish Environmental Administration, housing estate neighbourhoods are the least popular type of housing environment among Finns (Strandell, 2017). Another large survey in Finland focusing on the future aspirations of urban dwellers also confirmed that housing estate neighbourhoods are the least desired housing environments among all household and age groups living in urban areas (Haltia et al., 2019). The view of the residential real-estate company also strongly contrasts with the public and media debate, which has treated housing estate neighbourhoods as symbols of urban deprivation, unemployment, abuse, and broken families (Hyotylainen, 2019; Roivainen, 1999). In this paper, we turn our attention to this paradox. We address the under-researched phenomena of investments in the private rental markets in disadvantaged suburbs in Finland by exploring the developments in two housing estate neighbourhoods in the Helsinki Metropolitan Area: Myyrmäki in Vantaa and Myllypuro in the neighbouring city of Helsinki.

We define housing estate neighbourhoods as neighbourhoods with a large share of housing complexes that have been simultaneously developed and which share a rather uniform appearance. Most of the large-scale housing estate neighbourhoods in Finland date back to the first wave of urbanization in the 1960s and 70 s (Vaattovaara et al., 2018). The development follows a similar story as in many other places; during this time, a large amount of decent and affordable housing was produced for the growing population. For developers, this was an opportunity to achieve sizeable profits as there was a large demand for housing. However, similar to the international discourse on housing estate neighbourhoods, they also had become stigmatized in Finland by the end of the 1980s (Juntto, 1990). Vaattovaara et al. (2018) further noted a concentration of deprivation in Finnish housing estate neighbourhoods prevalent since the 1990s, including socio-economic decline, and growth in immigrant populations. Feelings of unrest and insecurity have increased in these neighbourhoods co-varying with a wish to move away (Vaattovaara et al., 2018). Housing estates are also typically understood as less attractive than other parts of the Helsinki metropolitan area, because the cheapest real-estate is found in these neighbourhoods. Indeed, one way to measure the attractiveness of a neighbourhood by the city of Helsinki is to compare its housing prices to other areas (e.g., Miettinen, 2018). However, both the media and the academic sphere seem to have paid scant notice to an ongoing development already apparent since 2015, namely, the most rapid increase in private rents has transpired in housing estate neighbourhoods (Statistics Finland, 2020a). As this paper will show, there is a resurge to invest in these neighbourhoods, which challenges in intricate ways the current narratives of housing estates and the social composition of these neighbourhoods.

The resurge to invest in housing estate neighbourhoods coincides with a strong migration to the Helsinki Metropolitan Area, creating a growing demand for housing. For example, in 2000-2019, the population of Helsinki grew from 561000 to 654000 inhabitants, and is predicted to grown further, resulting in 715000 inhabitants by 2029. In Vantaa, the population in the same period grew from 187000 to 234000 inhabitants, and is predicted to reach 283000 inhabitants by 2029. The growth is mostly immigrant population from abroad and their children (Helsingin seudun aluesarjat, 2020). Many housing estate neighbourhoods in the Helsinki Metropolitan Area are also the target for regeneration processes, often with the aim of enhancing a social mix, in particular, by diversifying the housing supply with more owner-occupation housing. For example, in 2006-2008, the city planning 
department of Helsinki created a general plan of'the renaissance of the suburbia" with the aim to densify the suburbs. The target was to increase the attractiveness of the suburbs by targeting both ecological (diminish carbon emissions) and social (more demand for public transport and other services, counteracting segregation) aims (Esikaupunkien renessanssi, 2020).

Against this empirical background, we seek to understand the changing position of housing estate neighbourhoods in the Helsinki Metropolitan Area. We start by building a framework based on literature on the financialization of rental housing, and the particular housing policy conditions under which the changes we study occur. We then analyse recent developments in two housing estate neighbourhoods, Myyrmäki and Myllypuro, guided by the following questions: (a) which are the specific local conditions in the estate neighbourhoods that have encouraged private rental investment?, and (b) how is the increasing presence of private rentals in the housing estate neighbourhoods changing the social profiles of the neighbourhoods? Lastly, we conclude and discuss the consequences of our findings.

\section{The marketization and financialization of rental housing}

The Nordic welfare model, which Finland also follows, is generally known for its broad welfare, corporalist coordination, and strong economic performances with egalitarian outcomes. However, within this same Nordic context, housing has become increasingly commodified with access to housing becoming an unequalising issue. For example, medianincome single-person households can find it difficult to buy even a studio apartment in the Nordic capital cities. Housing in the Nordic countries, including Finland, is presently understood as being an investment opportunity, and is judged by its market value (Tranoy et al., 2020). Therefore, housing has undergone marketization and become progressively financialized. The marketization on housing is characterized by a deregulation and withdrawal of state interventions in housing practices, and emphasizes the role of the market in providing housing for residents (Ruonavaara, 2017). The financialization of housing means "the increasing dominance of financial actors, markets, practices, measurements and narratives that transforms structures of economies, firms, states and households" (Aalbers, 2019, p. 4).

Janoschka et al., (2020, p. 1010) argue that in order to understand recent urban transformations, it is crucial to understand the politics of housing financialization. In the Nordic context, one of the few studies contributing to this thematic is that of Tranoy et al. (2020). Their argument asserts that the liberalization of the housing and credit markets combined with a long period of low interest rates have financialized the housing markets in Sweden, Norway, and Denmark. They postulate that by supplying creditworthy borrowers, the states have in fact spurred the financialization of housing through the social welfare model. There are high levels of income equality, extensive social insurance, and high female participation in the labour market, which define dual-earner families as the most common form of a family unit. All these features create creditworthy borrowers who have increasingly invested in the housing market. With their study, Tranoy et al. (2019) contribute to the main strain of housing financialization literature, which namely concentrates on homeownership (e.g., Fields \& Uffer, 2016). Nevertheless, since the 2007 financial crises, rental housing has been characterized by Belotti and Arbaci (2020) as the new "frontier for financialization". Thus, there is a growing body of research concentrating on the financialization of social and rental housing in different contexts. The main outcome of these studies 
is that cities and states also effectively participate in the financialization of housing. For example, Fields and Uffer (2016) compare the impacts of the financialization on tenants, neighbourhoods, and urban spaces in Berlin and New York. They conclude that despite being different, both cities have driven the financialization of housing: on the one hand, by weakening rental protection, and, on the other, by transforming affordable housing into what they call a global asset class. In a similar vein and from the perspective of the city of Toronto, August and Walks (2018) assert that the city is responsible for simultaneously creating an affordability crises for tenants as well as investment opportunities for financialized landlords through the withdrawal from social housing, deregulation of rental protections, and decontrolling of rents. Thus, financialized landlords extract value, for example, through rent increase; or on sensing the potential for gentrification, by turning affordable housing into luxury housing. Aigner (2020) further recognizes that even in Vienna, famous for its large share of available affordable housing, the city has transformed a share of newly produced housing into an investment product. In their study on two regions in Italy, Belotti and Arbaci (2020) posit that the interplay between national, regional, and local governments has led to the financialization of social housing production within that country. Gustavsson (2019) further shows in her study of Malmö, Sweden, that public housing in Sweden has become financialized through a number of interlocking national and local decisions during a lengthy span of 20-30 years. While the financialization of housing has been identified in various geographical regions. Engelen et al. (2010) and Fields and Uffer (2016), argue that there is still a need to identify the specific geographies of financialization. Thus, we next explore in more detail the Finnish housing policy development and further developments related to rental housing.

\section{Finnish Housing policy and the rise of private landlordism}

According to Ruonavaara (2017), a phase of retrenchment means that the government withdraws from its previous commitment to housing provision in order to provide more room for market forces; in Finland, it has also led to the strengthening of selectiveness in the housing policy (see also Hyötyläinen, 2019). In Finland, homeownership has been upheld as the ideal form of housing, whereas renting has been a secondary alternative. These values have also been reflected in housing policy, in which not only rental housing, but also homeownership has been widely subsidised (Juntto, 1990; Ruonavaara, 2017). Although owner-occupation in Finland has been understood as being significant to social rising, in Helsinki, renting has remained the urban way of dwelling for some time. Until the 1960s, most of the residents in Helsinki still rented their homes from the regulated private market. However, during the 1970s, a great number of private (rent-regulated) rental apartments in Helsinki were sold and used for owner-occupation. The newly built rental housing was mostly municipality-owned so-called government-subsidised rental dwelling housing ${ }^{1}$ (housing that in other contexts could be called non-profit housing or public housing), and most specifically, it was realized in housing estate neighbourhoods. Not only were housing

\footnotetext{
${ }_{1}$ Governmental bodies, municipalities, and government-subsidised rental dwellings organizations govern the government-subsidised rental dwellings housing stock. The rent of these flats are cost-based. The government annually specifies the criteria for eligibility, including the urgency of the applicant's housing need and their level of income (ARA, 2013, 2015).
} 
estate neighbourhoods pigeonholed, but government-subsidised rental dwellings were similarly classified (Herranen, 1997, pp. 224; 222).

Currently, the most common housing tenures in the Helsinki Metropolitan Area are owner-occupation, private rentals and government-subsidised rented dwellings. Private landlords encompass both private households and institutional investors. Homeownership in apartment blocks is realized through limited liability housing companies. Each share of the company provides the right of possession to specific apartments in the building with the shareholder holding the right to transfer the apartment to someone else. Therefore, a remarkable share of rental dwellings are situated in buildings with owner-occupation apartments as the owner may also choose to lease out their apartment. While living in rental housing has become more common, the offer of government-subsidised rented dwellings has decreased. Indeed, between 2000 and 2017, there was a decrease of -3 per cent of this type of rented dwelling in Helsinki, and -5 per cent in Vantaa. During the same period, the number of other (mostly private) rentals greatly increased, by 30 per cent in Helsinki and 93 per cent in Vantaa (ARA, 2019, p. 6). Two major bodies, Sato and VVO, used to provide government-subsidised rented dwellings. However, they have converted and sold off or transformed their holdings into private rentals. When a tenement is constructed with a government-subsidised loan, there are terminable restrictions concerning rent level and tenant selection. After the time limit (20-45 years), the owner can convert dwellings into market-based dwellings. Nonetheless, in contrast to the development in many other European countries since the 1970s, during which the provision of social rental housing has declined (Scanlon et al., 2014), the production of new government-subsidised rental dwellings has been maintained at acceptable levels in Finland, compensating for the substantial amount of conversions of government-subsidised rental dwellings. For instance, in the Helsinki Metropolitan Area, 14 municipalities have signed an agreement entailing specific goals for land use, housing production, and transport networks. In order for the government to finance large transport investments, each municipality has to agree to allocate 20 per cent of the new housing as government-subsidised rented dwellings (including government-subsidised rental dwellings rental flats, student housing, and dwellings for persons with special needs) (Helsingin seudun aluesarjat, 2020). The government-subsidised rental dwelling is a common way of living, particularly in the city of Helsinki, in which every fifth household lives in government-subsidised rented dwellings, most of which are owned by the city (Helsingin seudun aluesarjat, 2020).

The retrenchment of Finnish housing policy began in the 1990s. Part of the restructuring of housing policy in Finland was planned to increase the subsidies on the demand side versus the supply side. In other words, the current demand side subsidies, the subsidies directly allocated to households, manifoldly outnumber the supply side subsidies. The Finnish government substantially supports renters as evidenced by a housing allowance of altogether 2 billion euros being paid to 15 per cent of all Finnish households in 2018 (Tilastokatsaus, 2019). The number of recipients of general housing allowances for tenants has increased in the 2010s in both Helsinki and Vantaa (Ahlgren-Leinvuo, 2018). At the same time, according to Kettunen and Ruonavaara (2015), the rejection of rental regulation in the 1990s has actually been the clearest sign of retrenchment of the Finnish housing policy. Private renting was an unattractive alternative for investments until the 1990s, when rent regulation was abolished. According to Andersson et al. (2007), the welldeveloped legal protection of tenants also rendered it an undesirable way of earning money. Nevertheless, a number of reforms have encouraged the development of a private rental sector in Finland. In the Helsinki Metropolitan Area, 60 percent of all new developed housing were rentals in 2018, most of which were private rentals. In Finland as a whole, the 
number was 49 percent (Official Statistics of Finland, 2019). The Confederation of Finnish Construction Industries RT have estimated that out of the new housing production intended as owner occupation, one fourth is bought up by housing investors (Rakennusteollisuus RT 2017). Studios, which young adults would potentially most likely buy, are the most attractive to investors as they provide the best profit (Kannisto et al., 2019). Therefore, it has been claimed that a substantial number of studios in Helsinki are sold directly to or between investors, rather than to first-time buyers (Meriläinen, 2017). The institutional investors include listed and unlisted pension funds or private investment companies often partly owned by pension funds. The government has rendered investments in housing more attractive to pension funds, by passing a law in 2015 enabling pension funds to use a temporary leverage on fully-owned new rental housing properties (Karikallio, 2019). Private landlordism, on the other hand, has been enhanced by more lenient taxation of capital income, and the increasing number of private landlords has been sizeable. Individuals with an income from rents increased from 241391 persons to 317852 between 2006 to 2016 (Alho et al., 2018). This resembles the situation in many other contexts in which the practice of buy-to-let has grown (Forrest \& Hirayama, 2015; Ronald \& Kadi, 2017). The amount of people renting their dwellings has increased by 14 percent in the entire country during 2010-2017 (Suomen virallinen tilasto SVT, 2018).

Against these changes in the Finnish housing context, we explore and analyse the development in two housing estates in the Helsinki Metropolitan Area. By doing so, we respond to the appeal voiced by Nethercote (2020) who argues that more empirical understanding is needed to understand the financialization of rental housing. Through our two case studies, we show the variegated ways in which marketization and financialization take form in the Finnish context. Inspired by the claim of Hochstenbach and Ronald (2020), which asserts that it is not always easy to recognize the role that the state has played in supporting private rental housing, in our empirical investigation, we seek to simultaneously carve out the impact of urban planning, housing policy, and social welfare (particularly housing allowance and income support) in encouraging housing investments, and, consequently, the way in which rental housing also reshapes the socio-economic geography of housing estate neighbourhoods.

\section{Empirical context, data and methods}

The findings of this paper are based on a set of different data. To understand urban renewal policies, changes in housing costs, and the social structures of the neighbourhoods, we used a variety of sources of information. As our aim is to analyse the context and outcome of policy and planning interventions, we carefully chose these sources, but also used them in explorative ways.

A typical feature of Finnish suburban housing estate neighbourhoods, and of the housing sector in general, is the homogeneousness of the quality of the dwellings and the built environments. This is related to the strong norm regulation of construction and preconditions of public financing of the older housing production. Therefore, as living environments, housing estates with different social profiles resemble one another. A strong general egalitarian ideal in Finnish society has also been at work in the development of housing estate neighbourhoods (Puustinen, 2010); thus, both socioeconomic and ethnic residential segregation have stayed at a moderate level when internationally compared (Van Ham \& Tammaru, 2016), although minor signs of strengthening segregation have recently been noticed (Skifter Andersen et al., 2015; Hirvonen, 2019; van Ham \& Tammaru, 2016). 
Table 1 Statistics about two case areas (2018/2019. Data: Statistics Finland, Helsingin seudun aluesarjat, 2020)

\begin{tabular}{lllll}
\hline & Myllypuro & Myyrmäki & Helsinki & Vantaa \\
\hline Distance from Helsinki city centre via rail & $12 \mathrm{~km}$ & $13 \mathrm{~km}$ &. &. \\
Total population & 12567 & 17194 & 653835 & 233775 \\
Share of 0-17 year-old residents & $20 \%$ & $17 \%$ & $17 \%$ & $21 \%$ \\
Share of solo-dwellers of total population & $21 \%$ & $29 \%$ & $25 \%$ & $19 \%$ \\
Share of higher educated residents & $24 \%$ & $35 \%$ & $49 \%$ & $36 \%$ \\
Unemployment rate 2017 & $13 \%$ & $12 \%$ & $10 \%$ & $10 \%$ \\
Median equivalent disposable income, $€$ & 24073 & 23961 & 26501 & 26208 \\
Share of owner-occupied dwellings & $38 \%$ & $49 \%$ & $41 \%$ & $50 \%$ \\
Share of government-subidised rental dwellings & $30 \%$ & $15 \%$ & $19 \%$ & $16 \%$ \\
Share of private rental dwellings & $15 \%$ & $29 \%$ & $28 \%$ & $24 \%$ \\
\hline
\end{tabular}

Our housing estate neighbourhood cases in this study have both been subjected to urban renewal and densification. They are ideal to study as the urban renewal process in the estates is in a slightly different phase. They are also located in two different municipalities (Myllypuro in Helsinki, and Myyrmäki in Vantaa), with slightly different histories and institutional frameworks, in particular, around social mixing policies. The city of Helsinki has a stronger history of mixing different tenures in all neighbourhoods, and currently also administers and develops more government-subsidised rental dwellings. The next table (Table 1) summarises some of the basic features of our two case areas. Statistics on the two cities are included as baselines.

Our data included statistics, structural interviews, policy documents, newspaper articles, analysis of rents on commercial websites, and observation. We used sub-areal statistics, mostly from the statistical database of the Helsinki Region. This date set provides a wide and separate range of sub-area statistics for the housing stock and population.

We also interviewed four institutional investors in the Helsinki Metropolitan Area, four planners in Helsinki and Vantaa, as well as two civil servants in charge of tenant selection of government-subsidised rental dwellings owned by the city of Helsinki. We further analysed planning documents by the cities. Furthermore, the supply of private rentals in the neighbourhood of Myyrmäki was analysed on the commercial website Oikotie.fi. In addition, we visited the neighbourhoods on different occasions in order to understand the physical conditions of the areas.

\section{Case Myyrmäki}

Myyrmäki, situated in Vantaa, is a typical housing estate neighbourhood as 98.8 percent of the housing stock consists of high rises, a high figure compared to the city average (62\%). It has lately been subjected to urban renewal, both by the city of Vantaa and through residents' initiatives. Myyrmäki is one of the core areas that the city of Vantaa seeks to densify. The aim is to develop a high profile, lively urban centre. This has included upgrading of the shopping mall and expanding the local college. According to the main urban planner of Myyrmäki, the potential for housing in the area is vast. In addition to the urban renewal 


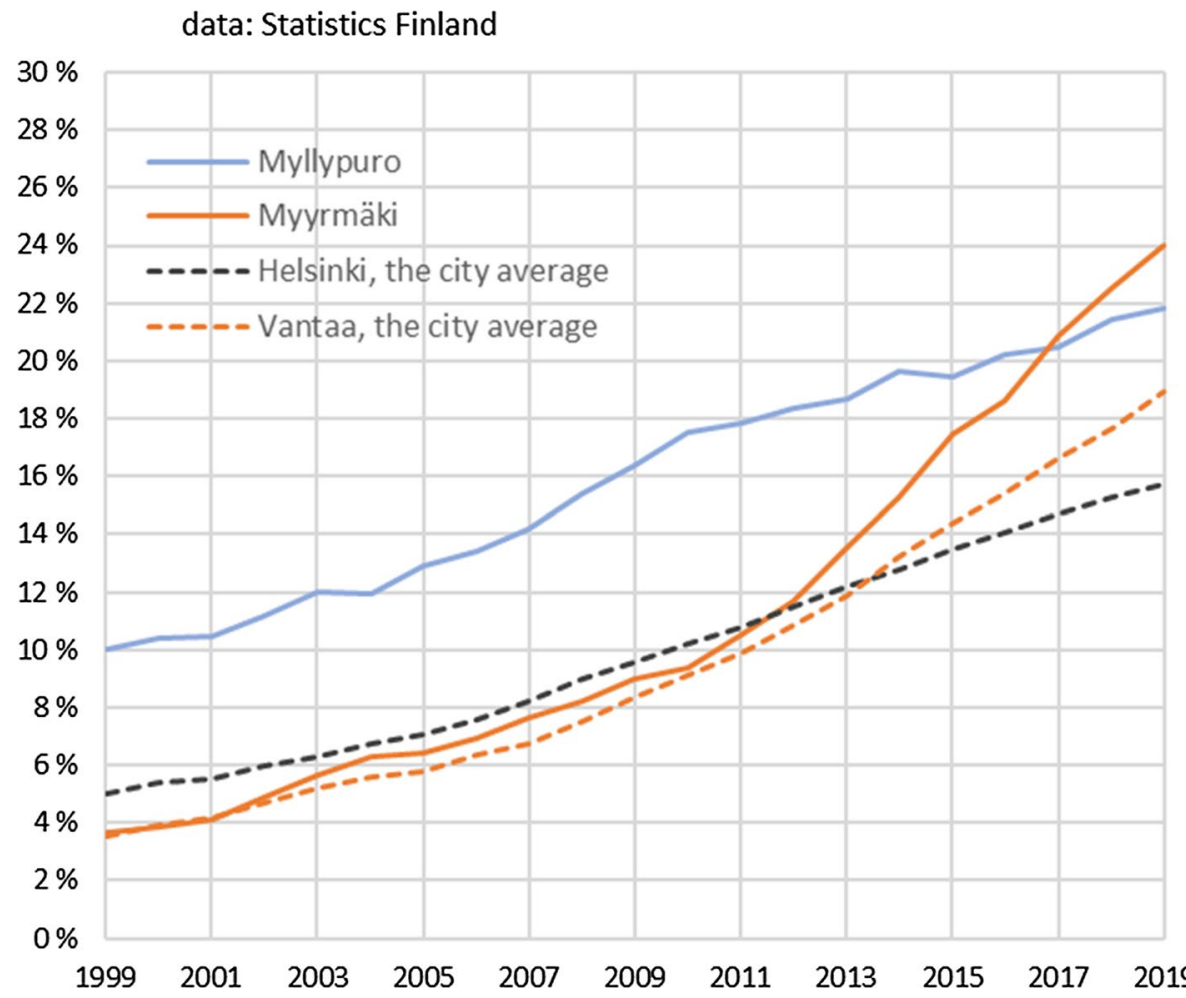

Fig. 1 The share of foreign language population by area 1999-2019 (31.12.), (Helsingin seudun Aluesarjat, 2020)

initiatives of the city, a number of positive newspaper articles have been published about the enhancement of the neighbourhood's sense of community brought about by the activism of its residents (Lilius, 2020). The number of residents in Myyrmäki is set to double within the next 10 years (City of Vantaa, 2017). The population of the statistical area of Myyrmäki is about 17,200 (2019) with a fourth of them coming from an immigrant background. The percent of foreign-background population has rapidly risen after 2010 and is now more than the Vantaa average (Fig. 1).

However, in the last few years, especially the number of foreign-background residents from poor, non-European countries has rapidly risen. The profile of the Myyrmäki foreignlanguage population has substantially changed in the seven last years. The number of Estonians and Russians has only modestly grown, while the numbers of Middle Eastern, other Asian, and African languages speakers has considerably increased (Fig. 2).

It is unclear exactly where the growing number of immigrants are located in Myyrmäki. Due to the data protection rules of statistics, this information is not available even for the use of research such as this. Nevertheless, several factors indicate that immigrants have settled in the growing private rental stock. In the Helsinki Metropolitan Area, a clear majority of households with a foreign background, especially non-European immigrants, live in a rented home (Saukkonen, 2016). The new immigrants since 2015, including asylum seekers, have applied less than expected for government-subsidised rental dwellings and have supposedly mostly chosen private rentals (Ruonavaara, 2017, p. 15). When choosing 


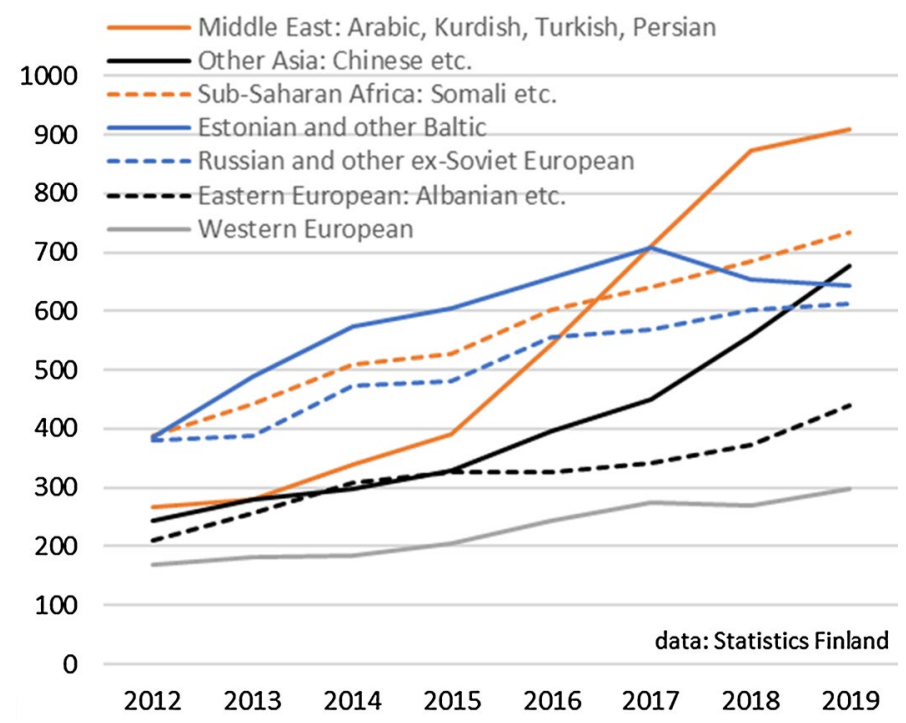

Fig. 2 Foreign-language population of Myyrmäki by language 2012-2019 (31.12.), persons (Population database of Helsinki Region)

residents for the government-subsidised rental dwellings, one of the criteria is that all buildings should have a mix of residents with different backgrounds. This explains the scarcity of government-subsidised rental dwelling buildings earmarked for housing only or mostly immigrants. However, our interviews with the institutional investors verify that they do not attempt to avoid an overrepresentation of some ethnicities in their apartment buildings. Therefore, there could potentially be a high share of immigrants in rental housing owned by institutional investors.

Around 5000 jobs are located in the Myyrmäki area (Myyrmäen kaavarunko, 2018) with the unemployment rate in Myyrmäki standing above the city average. The median income has been stable since 2012 and it has lagged behind the general income on the upgrade income level in Vantaa. The share of the lowest income quintile has risen from 18.5 percent to 23.7 percent in ten years. This may be connected to the high share of immigrants. The share of higher educated residents has stayed at the level of 35 percent in the 2000s, but has declined in relation to average increasing development in Vantaa. Again, due to data protection rules, it is not possible to clearly state any links between this factor and the high share of immigrants living in the neighbourhood. In recent years, dwelling prices have decreased below the Vantaa average prices (Tilastokeskus, 2020a). All these trends would indicate the declining socio-economic status of Myyrmäki (Table 1 and Figs. 3, 4 and 5).

Nevertheless, when looking at rental housing, the trend looks quite different. Rents have greatly increased. It is not possible to extract exact numbers for Myyrmäki as comprehensive statistics of all rents are unavailable. However, by looking at the rents of recipients of the general housing allowance in Myyrmäki, we can see that between 2016-2019, the rents increased by 7.4 percent (from 15.9 to $17.1 € / \mathrm{m} 2$, government-subsidised rental dwellings are not included) (The Social Insurance Institution of Finland, 2020).

A little less than half of the dwellings in Myyrmäki are owner-occupied. About every sixth apartment is government-subsidised rental dwelling. In the first instance, they are 


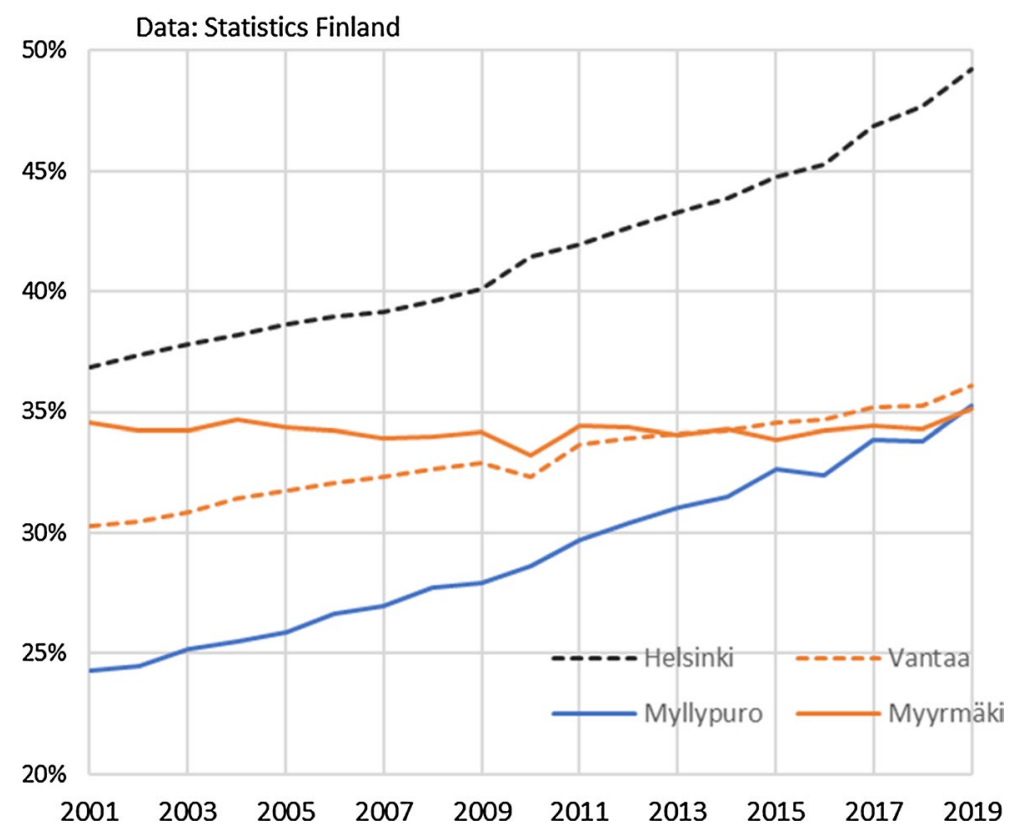

Fig. 3 The share of higher educated residents by area 2000-2019, per cent, population of $25+$ years (Helsingin seudun aluesarjat, 2020)

owned by the municipality. The share of the other (mostly private) rentals is almost 30 per cent (Fig. 6). However, the six last years has been a period of substantial housing construction in Myyrmäki. The housing stock has increased from about nine thousand to more than ten thousand dwellings. At the same time, the tenure structure has markedly changed: The numbers of owner-occupied and government-subsidised rental dwellings have diminished while the number of private rentals has almost doubled in the last six years. (Table 2).

According to the city's housing policy, half of the new housing in Myyrmäki is to be realized as owner-occupation and half as rental housing. Out of this rental housing, 20 percent must be government-subsidised rental dwellings. Yet, the number of owner-occupied flats has decreased despite the new constructions.

Based on the Table 2, we can conclude that the financialization of the rental housing stock is apparent, and it includes both the converted government-subsidised rental dwellings as well as new production. First of all, despite the new construction of governmentsubsidised rental dwellings of at least 105 flats, the total number of government-subsidised rental dwellings has reduced by about 130 flats. This is due to the government-subsidised rental dwellings being converted into private rentals when the state-guaranteed loan period and its associated restrictions have ended. This seems to have created good opportunities for profit-making. As it is not possible to statistically verify the rent increase in these flats, we have instead tried to understand the developmental arc of rents based on the average rent in the old housing stock from the 1970s on flats available to rent in Myyrmäki on oikotie.fi, ${ }^{2}$ Finland's largest internet site for rental apartments. In buildings from 1966, ‘69, ' $71, ' 72, ' 74$, and' 77 , the average rent of the 16 available flats (ranging in size from $12 \mathrm{~m}^{2}$

$\overline{2}$ The calculation is done based on available flats for rent on Oikoti.fi in Myyrmäki 26.2.2020. 


\section{Data: Statistics Finland}

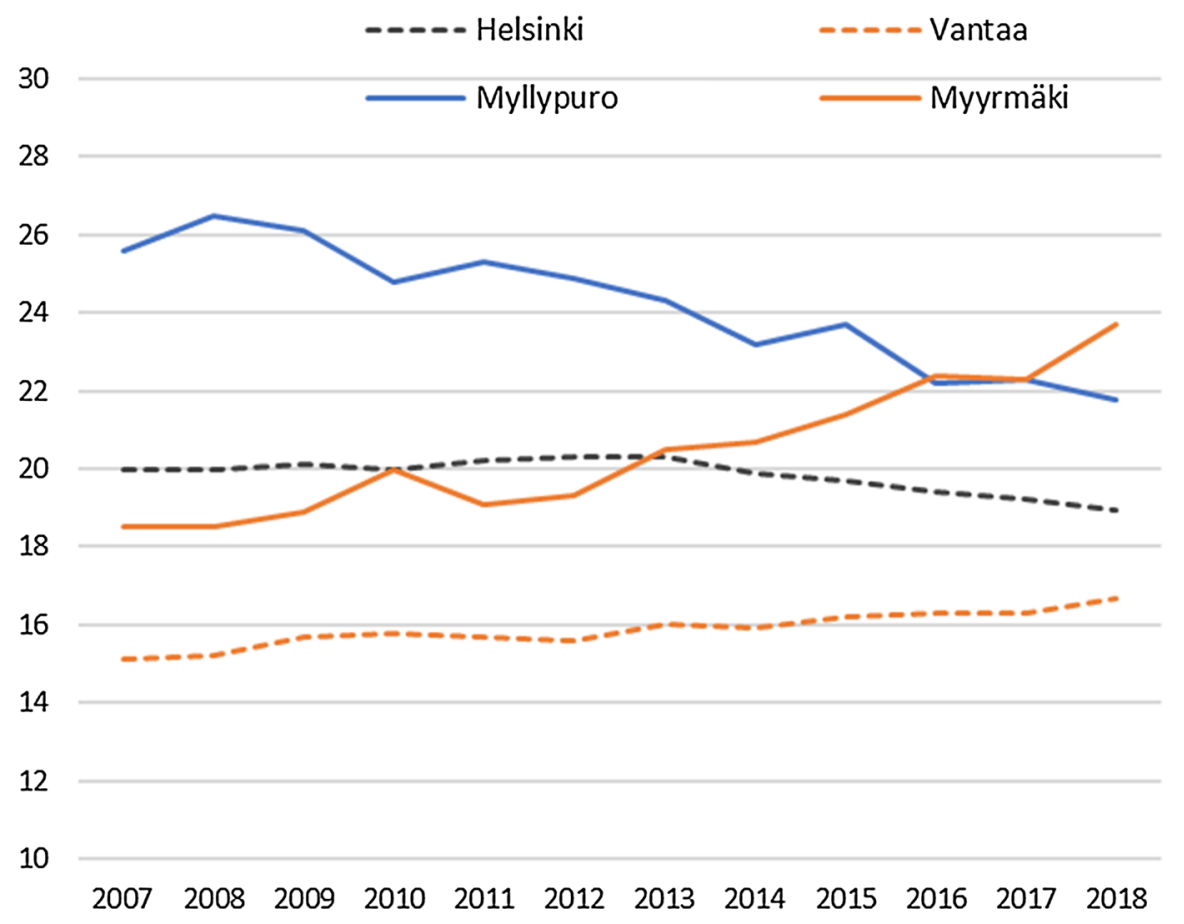

Fig. 4 The share of the lowest income quintile 2007-2018 by area, per cent (equivalent disposable income), (Helsingin seudun aluesarjat, 2020)

to $71 \mathrm{~m}^{2}$ ) was $19.5 € / \mathrm{m}^{2}$. Considering the time of their construction, they are likely to be converted government-subsidised rental dwellings. Based on the pictures in the advertisements, there is an indication that the flats have undergone some modest renovations, which has slightly upgraded the flats from their 1970s style. However, the rent is above the Vantaa average of all tenancies (17.2 €/m2, Statistics Finland, 2020a).

Secondly, although most of the new production was owner-occupation, the dwelling sizes have been private studios or one-bedroom apartments. The new construction in 2014-2019 has mostly included small flats: 81 per cent are one- or two-room apartments. In the whole housing stock in Myyrmäki, the share of small flats is much less: 56 percent. As we have already mentioned, small flats are particularly attractive investments (Kannisto et al., 2019). The city of Vantaa estimates that 30 to 50 per cent of the new owner-occupation has ended up as private rentals. Further, according to the institutional developers, it is the small sizes they are interested in developing.

Myyrmäki as a place to invest in is interesting to the large institutional developers for several reasons. There are many reasons for its attractiveness: the location is close to a train station with good connections to downtown Helsinki and the airport; there are good services and a nice layout. Indeed, it is the housing that institutional developers want to develop in Myyrmäki: 




Fig. 5 Average prices of old dwellings in housing companies by area 2010-2019, €/m2 (Statistics Finland, 2020b)

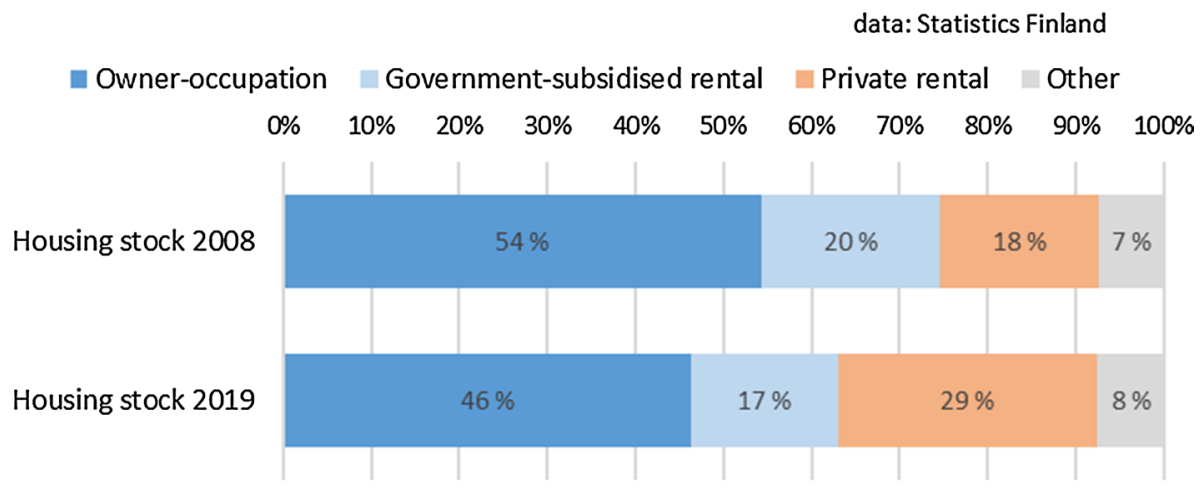

Fig. 6 The housing stock of Myyrmäki 2013 and 2019 (31.12.) by tenure, per cent (Helsingin seudun aluesarjat, 2020)

Opposed to office premises, the area is very interesting in terms of housing with us developing quite a bit there, because there are many people moving there, and it's quite a cosy place with services, schools, and child-care close by... (Investor B).

Furthermore, as the cost of land is less expensive than elsewhere in the Helsinki Metropolitan Area, it is a particularly attractive area in which to develop rental housing.

It is also of considerable value to the investors that the city is developing the area: 
Table 2 The change of the tenure structure in Myyrmäki 2013-2019 (Helsingin seudun aluesarjat, 2020)

\begin{tabular}{llll}
\hline Tenure & $\begin{array}{l}\text { Housing stock } \\
2013\end{array}$ & Housing stock 2019 & Change 2013-19 \\
\hline Owner-occupied & 4901 & 4750 & -151 \\
Government-subsidised rental & 1844 & 1715 & -129 \\
Private rental & 1618 & 3026 & 1408 \\
Right of residence & 201 & 201 & 0 \\
Other/unknown & 477 & 572 & 95 \\
Total & 9041 & 10264 & 1223 \\
\hline
\end{tabular}

...And we believe that the city of Vantaa is committed to developing the area. (Investor B)

New apartments and the development of, for example, a new shopping centre with a clear image, well, it clearly raises the value of older apartments, too, and the attractiveness of the area (Investor C)

In addition, on their webpages, the institutional real-estate investors strongly build on the image of Myyrmäki as a gentrifying area with a working-class image (Lilius, 2020), thus implying that a rent gap exists in the housing estate neighbourhoods.

As elsewhere in the city, there has also been a substantial rise in private rents in Myyrmäki. There is also reason to emphasise that rents are typically higher in new tenancies than in old ones. Concurrently, little to no new flats are available on oikotie.fi, which would indicate that they might have already been leased. The high rents and the growing number of immigrants might imply that many are housed in expensive rental flats with rents paid to a large extent by government bodies.

\section{Case Myllypuro}

Our other case represents a housing estate neighbourhood in which changes have been ongoing for longer. The urban renewal of the city of Helsinki's showpiece neighbourhood Myllypuro already started in the first decade of the 2000s. Located in eastern Helsinki, the most stigmatized part of the Helsinki Metropolitan Area, the city has for decades aimed to increase the attractiveness of the area. The renewal in Myllypuro began with the demolishing of the old shopping centre built in the 1960s. The new shopping centre was developed by Citycon, a large real-estate investor and developer (also active in Myllypuro), and was completed in 2012. In addition, the decision was also made to place one of the main campuses of the university of applied sciences Metropolia with 6000 students and 500 employees, in Myllypuro. The campus is considered to create "an open network and environment for learning and innovation boosting the area's vitality" (Metropolia.fi, 2020). The city of Helsinki considers the development in Myllypuro to be a success story as the social profile of the area has been upgraded and the feeling of safety has increased (Keskinen \& Laihinen, 2015, p. 44; Pulkkinen \& Idström, 2017, pp. 55-56). Studies in Finland have shown that compared to government-subsidised rental housing-dominated neighbourhoods, a more mixed tenure structure has entailed a less disadvantaged and more regulated 
data: Statistics Finland

Owner-occupation

- Private rental

Other/unknown
Government-subsidised rental

Right of residence



Fig. 7 The housing stock of Myllypuro 2009 and 2019 (31.12.) by tenure, per cent, (Helsingin seudun aluesarjat, 2020)

local community, which paves the way for a more peaceful local social life and better subjective security (Kemppainen, 2017, pp. 74-81).

Out of the almost 13,000 residents of Myllypuro, just over a fifth possess a foreign background, which is a little more on average than in Helsinki. The share of foreign-background population has risen following the general development in Helsinki, but not at a more rapid pace. In Myllypuro, the socio-economic population structure and status has become upwardly mobile. Since 2005, the median income has increased in phases within the whole of Helsinki, and faster than in the surrounding neighbourhoods in eastern Helsinki. The share of the lowest income quintile has declined from 26 to 22 percent in the last ten years. In Myllypuro, the share of higher educated residents has risen faster than in the eastern major district of Helsinki. The rise of the education level has been the most obvious in complementary construction areas with terraced houses and one-family houses, but the education level has also risen in older sub-areas with blocks of flats (Tavi, 2019). (Figs. 1, 3 and 4.)

The housing production has been substantial in Myllypuro in the 2000s. In the last 11 years, new production has included 1550 dwellings and the housing stock has been enhanced from about 5000 to 6500 . The new production has mostly been owner-occupied (38\%) and right of occupancy (38\%) dwellings. The share of right of occupancy dwellings has substantially risen from 3 to 11 percent (Fig. 7). The aim in Helsinki is that 25 percent of the housing production would be realised as government-subsidised rental housing (including housing for young people, student housing, housing for people with special needs, and government-subsidised rental dwellings rentals); 30 percent as Hitas housing (the city's own owner-occupation housing), partial ownership housing, and right-of-occupancy housing; and 45 per cent as unregulated rental and owner-occupied housing production. In addition, apartments in the old housing stock have been renovated. In Myllypuro, new production in the eleven last years has mostly (64\%) been larger family dwellings of 3 +rooms. Out of the new production, 38 percent has been terrace houses, and the rest, blocks of flats.

The housing prices in Myllypuro have risen faster than in surrounding housing estate neighbourhoods. In 2010, Myllypuro was distinctly below the other areas, whereas in 2019 Myllypuro has surpassed it (Fig. 5). Miettinen (2018) analysed local housing prices in 
Myllypuro and found that there was a significant increase in prices right after the completion of the shopping mall (2012), which also included housing. In other words, it appears that there is a direct connection between urban renewal and housing prices in the old housing stock. Miettinen (2018, p. 9) considers that this can have undesirable side-effects: the increased housing costs might force some low-income residents to move away and be replaced by new, wealthier residents. Nevertheless, the city of Helsinki may also be fuelling this development in the government-subsidised housing stock that the city owns. While the share of government-subsidised housing has remained at the same level of 30 per cent as in earlier years, the city has renewed the rent-setting system for their government-subsidised rented dwellings. The new system is based on the principle that market rents in the area should be reflected in the government-subsidised rented dwellings rents. Therefore, the city uses information about the current market rents in all neighbourhoods in Helsinki. They buy this information from KTI Benchmarking, a company that provides performance measurements as well as analyses for portfolio and asset management. Consequently, the city of Helsinki increased the rents in their own government-subsidised rental dwellings in Myllypuro by 2.5 per cent in 2018, which is much more than in any other neighbourhood. The increase is not very remarkable, but points to the tendency that cost-based rents should be upscaled by market rents. As the government-subsidised rental dwelling rents in Myllypuro have been among the lowest in the city, it also signifies that low-income households may be paying the price for the increased investment in the area.

\section{Discussion}

Through our first case study in Myyrmäki, we have shown how the city's urban renewal policies fuelled private rental investments by creating an atmosphere of trust amongst the investors. In Myyrmäki, we saw a remarkable increase in the supply of private rental flats, and based on the growth in rents among those on housing allowance, we also concluded that the levels of the private rents have increased. Yet, despite higher rents, we did not see an increase in the income of the residents. Hulse and Reynolds (2018) term this development 'investification', referring to private households who invest in disadvantaged suburbs, thus contributing to higher prices in areas in which they would not like to themselves live. As Shaw (2009, pp. 246) claims, regeneration does not necessarily lead to displacement, but this requires intervention. In the past years, Finland has seen a remarkable increase in the number of households receiving housing allowances. This would imply that, to some extent, the state prevents the displacement of tenants despite rising rents. Thus, in order to fully grasp the financialization of housing in disadvantaged neighbourhoods, we recognize an urgent need to further study the possible interpretation that housing allowances act as a state-led tool which is fuelling the financialization of rental housing.

Our second case, that of Myllypuro, revealed the strategy adopted by the city of Helsinki, which is to gentrify the social strata of Myllypuro by employing an urban planning strategy aimed at creating social diversification. Hackworth \& Smith (2001) has defined gentrification as the production of space for progressively more affluent users. Using social mix as a strategy to lift the socio-economic profiles of neighbourhoods is a well-known strategy within urban planning (e.g., Hackworth \& Smith, 2001; Wyly \& Hammel, 2001; Lees, 2008). However, as has been argued elsewhere (Lilius, 2019), there is little intellectual or public debate in Finland on the aim of planners to 
reproduce not only the inner city, but also the suburbs and housing estates for more affluent users. The inner parts of Helsinki have already outpriced middle-class families; therefore, the city also actively seeks places to accommodate this group that typically is considered to consist of so-called good taxpayers. To Brattbakk and Hansen (2004, pp. 312) "a core question is how to increase the steam and attraction of large housing estates, while at the same time preventing the exclusion of the disadvantaged population from these housing markets". The city of Helsinki shows signs of choosing a different path. By raising the rents of their own government-subsidised rental housing stock in Myllypuro more than in any other neighbourhood, they are clearly also taking a stand on the type of residents they seek in their own housing stock. According to Karikallio et al. (2019), the occurring problems in many neighbourhoods for lowincome residents to "stay put" is recognised in cities and by government bodies. Here again, the national housing allowance may help to avoid displacement of residents. However, the question is still raised as to the extent to which market rents should influence non-profit rents; and more broadly, it queries if such tendencies to rely on the market are reflected in the city's housing policy on a broader level.

Why have our cases developed differently? The Myllypuro case would imply that a key success factor in socially upgrading the neighbourhood was the demand by the city encouraging developers to provide larger apartments. The new production in Myllypuro has been mainly larger flats in both terrace houses and blocks of flats, while those in Myyrmäki have been mostly small flats. The city of Vantaa has lately tried to encourage the development of larger flats (which potentially would not be as attractive for investment purposes). Since 2019, only 30 percent of the apartments in new apartment-building blocks can be studios, and at least 30 percent have to be at least two-bedroom apartments (Ranta, 2020). This may also decrease the number of owneroccupation flats that end up as buy-to-lets. Nevertheless, we conclude that the future of the housing estates neighbourhoods depends on the intricate outcomes of national housing policies as well as city-specific land use policies and plans.

Fields and Uffer (2016, pp. 1498) have argued that financialization "does not lead to one final outcome; instead, it continuously reshapes the urban landscape". We are aware that our paper also draws on weak signals, resulting in a lack of verifying data. Nevertheless, we believe that this may to some extent explain the interest of Finnish researchers towards the decline of housing estate neighbourhoods, instead of scrutinizing the emerging rent gap. Thus, although this paper is a modest contribution, we argue that housing estates have to be viewed much more vividly as well as analysed by using a variety of data. Nonetheless, we also contend that without proper statistical data on rent levels in specific buildings as well as information on those who settle in the buildings, it is also impossible for policy makers to fully grasp the consequences of events on the housing estates.

\section{Conclusions}

This paper set out to understand how investments in the private rental markets are changing the socio-economic geography of housing estate neighbourhoods in the Helsinki Metropolitan Area-areas that have typically been stigmatized both nationally and internationally (Hyotylainen, 2019; Norris et al., 2019; Roivainen, 1999). Our paper has demonstrated a rent gap in housing estate neighbourhoods; and based on our two 
case studies, we conclude that the rent gap has been fuelled by population growth, a changing national housing policy framework, and local regeneration policies. Thus, our results echo those of earlier studies, which have shown that the financialization of rental housing happens in an interplay between the financial investors and the enablers: the national, regional, or local governments (e.g., Belotti \& Arbaci, 2020). Nevertheless, the particularity of our study is that these developments have often not been connected to housing estate neighbourhoods. Simultaneously and additionally, we have shown that rental housing is also the new "frontier for financialization" (Belotti \& Abaci, 2020) in the Nordic context. Tranoy et al. (2020) have claimed that, by supplying credit-worthy borrowers, the social welfare model has spurred the financialization of housing in the Nordic countries. We argue that it is worth discussing the extent to which the social welfare model in Finland, with its generous housing allowance, has spurred on and enabled the financialization of rental housing in housing estate neighbourhoods.

Acknowledgements The authors would like to thank the reviewers and special issue editors for very helpful comments on ways to improve the paper.

Funding Open access funding provided by Aalto University. The research was funded by Svenska Kulturfonden under the postdocpool-grant framework.

\section{Declarations}

Conflict of interest The authors declare that they have no conflict of interest.

Open Access This article is licensed under a Creative Commons Attribution 4.0 International License, which permits use, sharing, adaptation, distribution and reproduction in any medium or format, as long as you give appropriate credit to the original author(s) and the source, provide a link to the Creative Commons licence, and indicate if changes were made. The images or other third party material in this article are included in the article's Creative Commons licence, unless indicated otherwise in a credit line to the material. If material is not included in the article's Creative Commons licence and your intended use is not permitted by statutory regulation or exceeds the permitted use, you will need to obtain permission directly from the copyright holder. To view a copy of this licence, visit http://creativecommons.org/licenses/by/4.0/.

\section{References}

Aalbers, M.B. (2019) Financialization. In: D. Richardson, N. Castree, M.F.Goodchild, A.L. Kobayashi and R. Marston (Eds) The International Encyclopedia of Geography: People, the Earth, Environment, and Technology. Oxford: Wiley.

Ahlgren-Leinvuo (2018). Yleinen asumistuki Helsingissä 2017 [General housing allowance in Helsinki 2017]. Tilastoja 2:2018. Helsingin kaupunginkanslia. [City of Helsinki, Executive office]

Aigner, A. (2020). What's wrong with investment apartments? On the construction of a 'financialized' rental investment product in Vienna. Housing Studies. https://doi.org/10.1080/02673037.2020.1806992

Alho, E., Härmälä, V., Oikarinen, E., Kekäläinen, A., Noro, K., \& Tähtinen, T., et al. (2018). Vuokraasuntosijoitusalankannattavuus, kilpailutilanne ja kehittämistarpeet. Valtioneuvoston selvitys- jatutkimustoiminnan julkaisusarja 9/2018. https://julkaisut.valtioneuvosto.fi/bitstream/handle/10024/160708/ 9-2018-Vuokra-asuntosijoitusalan\%20kannattavuus\%20kilpailutilanne\%20ja\%20kehittamistarpeet.pdf.

Andersson, E., Naumanen, P., Ruonavaara, H., \& Turner, B. (2007) Housing, socio-economic security and risks. A qualitative comparison of household attitudes in Finland and Sweden. European Journal of Housing Policy, 7(2), 151-172. https://doi.org/10.1080/14616710701308547.

ARA 2019. Selvitys 1/2019. ARA-asuntokannan kehitys 2000-luvulla. Retrieved January, 6, 2020 from https://www.ara.fi/download/noname/per cent7B2BFEDA80-81C6-492B-85EF-1640084C85F1per cent7D/143134. 
August, M., \& Walks, A. (2018). Gentrification, suburban decline, and the financialization of multifamily rental housing: The case of Toronto. Geoforum, 89, 124-136. https://doi.org/10.1016/j.geofo rum.2017.04.011

Belotti, E., \& Arbaci, S. (2020). From right to good, and to asset: The state-ledn financialisation of the social rented housing in Italy. EPC Politics and Space. https://doi.org/10.1177/2399654420941517

Brattbakk, I., \& Hansen, T. (2004). Post-war large housing estates in Norway - Well-kept residential areas still stigmatised? Journal of Housing and the Built Environment, 19(3), 311-332. https://doi.org/10. 1007/s10901-004-0697-9

Byrne, M., \& Norris, M. (2019). Housing marketfinancialization, neoliberalis and everyday retrenchment of social housing. EPA Economy and Space. https://doi.org/10.1177/0308518X19832614

City of Vantaa (2016). Vantaa alueittain 2015. http://www.vantaa.fi/instancedata/prime_product_julkaisu/ vantaa/embeds/vantaawwwst ructure/124282_Vantaa_alueittain_2015.pdf

City of Vantaa (2017). Tietoja Myyrmäen suuralueelta. https://webcache.googleusercontent.com/search? q=cache:4sLVB21EyEsJ:https://www.vantaa.fi/instancedata/prime_product_julkaisu/vantaa/ embeds/vantaawwwstructure/108646_Tietoja_Myyrmaen_suuralueelta.pptx $+\& \mathrm{~cd}=1 \& \mathrm{hl}=\mathrm{en} \& \mathrm{ct}=$ $\operatorname{clnk} \& g l=f i$

Engelen, E., Konings, M., \& Fernandez, R. (2010). Geographies of financialization in disarray: The Dutch case in comparative perspective. Economic Geography, 86(1), 53-73.

Esikaupunkien renessanssi [The renaissance of suburbia] (2020). The city planning department of Helsinki, publications 2008:16.

Fields, D., Uffer, S., 2016. The financialisation of rental housing: a comparative analysis of New York City and Berlin. Urban Stud. 53 (7), 1486-1502. https://doi.org/10.1177/0042098014543704

Forrest, R., \& Hirayama, Y. (2015). The financialization of the social project: Embedded liberalism neoliberalism and homeownership. Urban Studies, 52(2), 233-244. https://doi.org/10.1177/00420 98014528394

Gustafsson, J. (2019). Spatial, financial and ideological trajectories of public housing in malmö, Sweden. Housing Theory and Society. https://doi.org/10.1080/14036096.2019.1686061

Hackworth, J., \& Smith, N. (2001). The changing state of gentrification. Tijdschrift Voor Economische En Sociale Geografie, 22, 464-477. https://doi.org/10.1111/1467-9663.00172.

Helsingin seudun aluesarjat (2020): [Statistical database of Helsinki Region] http://aluesarjat.fi/.

Herranen, T. (1997). Kaupunkisuunnittelu ja asuminen. In: Turpeinen; T. Herranen; K. Hoffmann (eds). Helsingin historia vuodesta 1945. Osa 1: Väestö, kaupunkisuunnittelu ja asuminen, elinkeinot (121-168). Helsinki: Oy Edista AB.

Hirvonen, Jukka (2019): Asumisen etninen eriytyminen Helsingissä ja muualla [Ethnic residential segregation in Helsinki and elswhere]. Kvartti/Helsinki Quarterly 4/2019.

Hochstenbach, R.\& Ronald, R. (2020). The unlikely revival of private renting in Amsterdam: Re-regulating a regulated housing market, Environment and Planning A: Economy and Space. DOI: https:// doi.org/10.1177/0308518X20913015

Hulse, K., \& Reynolds, M. (2018). Investification: Financialisation of housing markets and persistence of suburban socio-economic disadvantage. Urban Studies. https://doi.org/10.1177/0042098017 734995

Hyotylainen, M. (2019). Divided by Policy: Urban Inequality in Finland. Doctoral Dissertation, University of Helsinki. Available at: http://urn.fi/URN:ISBN:978-951-51-3376-2.

Janoschka, M., Alexandri, G., Orozco Ramos, H., \& Vives-Miró, S. (2020). Tracing the socio-spatial logics of transnational landlords' real-estate investment: Blackstone in Madrid. European Urban and Regional Studies. https://doi.org/10.1177/0969776418822061

Juntto, A. (1990). Asuntokysymys Suomessa: Topeliuksesta tulopolitiikkaan. Helsinki: Valtion painatuskeskus.

Kannisto, O.; P. Kokkonen; M. Korhonen; E. Vuorio (2019). Myös yksiöiden rakennusbuumi hiipuu mitä tilastot kertovat ilmiöstä? http://www.stat.fi/tietotrendit/artikkelit/2019/myos-yksioiden-raken nusbuumi-hiipuu-mita-tilastot-kertovat-ilmiosta/

Karikallio H., Keskinen P., Kiviholma S., Reijonen J., Ruuskanen, O.-P. Vuori L., Härmälä, V. \& Lamminkoski, H. (2019). Pienten asuntojen osuus asuntotuotannossa ja vaikutukset asuinalueiden eriytymiseen. PTT Raportteja 262.

Kemppainen, T. (2017): Disorder and insecurity in a residential context. A study focusing on Finnish suburban housing estates built in the 1960s and 1970s. Research series 2017:2, City of Helsinki, Executive Office, Urban Research and statistics.

Keskinen, V. \& E. Laihinen (2015). Kaikesta huolimatta turvalista. Helsingin turvallisuustutkimus 2015. City of Helsinki Urban Facts, Research Series 2/2015. https://www.hel.fi/hel2/tietokeskus/julka isut/pdf/17_04_05_Tutkimuksia_2_Keskinen_Laihinen.pdf. 
Kettunen, H., \& Ruonavaara, H. (2015). Discoursing deregulation: the case of the Finnish rental housing market. International Journal of Housing Policy, 15, 187-204.

Haltia et al. (2019). Kaupunkiseutujen asukkaiden asumispreferenssit - Miten ja missä kaupunkilaiset haluavat asua? PTT Reports 260. www.ptt.fi.

Lees, L. (2008). Gentrification and social mixing: Towards an inclusive urban renaissance? Urban Studies, 45(12), 2449-2470. https://doi.org/10.1177/0042098008097099

Lilius, J. (2019). 'Mentally, we're rather country people' - planssplaining the quest for urbanity in Helsinki Finland. International Planning Studies. https://doi.org/10.1080/13563475.2019.1701425

Lilius, J. (2020). MyyrYork - rejuvenating a housing estate neighborhood for the next generation of residents. In Krase \& J. N. DeSena (Eds.). Gentrification around the World, Volume II. Palgrave Macmillan.

Meriläinen, U. (2017). Sijoittajat kahmivat kasvukeskusten pienet asunnot - kokonaisia kerrostaloja myyty päivässä. 10.5.2017. https://yle.fi/uutiset/3-9604831

Metropolia.fi (2020). Myllypuro Campus Campus for Builders of Well-being https://www.metropolia.fi/ en/about-us/campuses/myllypuro-campus

Miettinen, A. (2018): Myllypuron omistusasuntojen hintakehitys esimerkkinä Helsingin aluekehittämistoimien vaikutuksista. Julkaistu 06.04.2018. Kvartti/Helsinki Quarterly.

Musterd, S. \& W.P.C. van Gent 2016. Changing welfare context and income segregation in Amsterdam and its metropolitan area, 2004-2011." In: T. Tammaru, S. Marcińczak, M. van Ham \& S. Musterd (Eds.), Socio-Economic Segregation in European Capital Cities; East meets West, 55-79. London: Routledge.

Myyrmäen kaavarunko (2018). City of Vantaa. https://www.vantaa.fi/instancedata/prime_product_julka isu/vantaa/embeds/vantaawwwstructure/139285_kaavarunko_asukasilta07052018.pdf

Nethercote, M. (2020). Build-to-Rent and the financialization of rental housing: Future research directions. Housing Studies, 35(5), 839-874. https://doi.org/10.1080/02673037.2019.1636938

Norris, M., Byrne, M., \& Carnegie, A. (2019). Combatting stigmatisation of social housing neighbourhoods in Dublin Ireland. International Journal of Housing Policy, 19(2), 254-266. https://doi.org/ $10.1080 / 19491247.2018 .1532673$

Official Statistics of Finland. (2019). Suomen virallinen tilasto (SVT): Asunnot ja asuinolot [verkkojulkaisu]. ISSN=1798-6745. Yleiskatsaus 2019, 1. Asuntokanta 2019 . Helsinki: Tilastokeskus. Available at http://www.stat.fi/til/asas/2019/01/asas_2019_01_2020-10-14_kat_001_fi.html. Accessed 20 Aug 2021.

Pääkaupungin alakeskusten profiilit (2014). Suomen ympäristökeskuksen raportteja 18/2014. http://www.ymparisto.fi/fi-FI/Elinymparisto_ja_kaavoitus/Yhdyskuntarakenne/Tietoa_yh dyskuntarakenteesta/Julkaisujen_liitemateriaaleja(26076)

Pulkkinen, E. \& A. Idström (2017). Muuttuva Myllypuro- katsaus esikaupunkialueen menneisyyteen ja nykypäivään. City of Helsinki, Urban Facts, Working papers 1/2017. https://www.hel.fi/hel2/tieto keskus/julkaisut/pdf/17_08_23_Tyopapereita_01_Pulkkinen_Idstrom.pdf.

Puustinen, Sari (2010): Asumisen arvot ja tavoitteet. Teoksessa Norvasuo, Markku (ed.): Asutaan urbaanisti! Yhdyskuntasuunnittelun tutkimus- ja koulutuskeskuksen julkaisuja B 99. Espoo.

Rakennusteollisuus RT (2017). Rakennusteollisuus RT:n teemakatsaus: Asuntomarkkinat https://www. rakennusteollisuus.fi/globalassets/suhdanteet-ja-tilastot/teemakatsaukset/190217_rakennusteollis uuden-teemakatsaus-asuntomarkkinat.pdf.

Ranta, R. (2020). Pienet asunnot Vantaalla. Yhdyskuntasuunnittelu, 1/2020.

Roivainen, I. (1999). Sokeripala metsän keskellä: Lähiö sanomalehden konstruktiona . Helsingin kaupungin tietokeskus.

Roivanen, R. (1999). Sokeripala metsän keskellä - lähiö sanomalehden konstruktiona. Doctoral dissertation. University of Tampere.

Ronald, R., \& Kadi, J. (2017). The revival of private landlords in britain's post-homeownership society. New Political Economy. https://doi.org/10.1080/13563467.2017.1401055

Ruonavaara, H. (2017). Retrenchment and Social Housing: The Case of Finland. Critical Housing Analysis. Volume 4 | Issue 2 | 2017 | 8-18, Available online at www.housing-critical.com, DOI: https:// doi.org/10.13060/23362839.2017.4.2.382

Saukkonen, Pasi (2016). Maahanmuuttajien kotoutuminen Helsingissä: työllisyys, tulot ja asuminen. City of Helsinki, Urban Facts, Study Reports 2016:12.

Scanlon, K., Whitehead, C., \& Fernández Arrigoitia, M. (2014). Social Housing in Europe. Wiley \& Blackwell.

Shaw, K. (2009). Rising to a challenge. In K. Shaw \& L. Porter (Eds.), Whose Urban Renaissance? An International Comparison of Urban Regeneration Strategies (pp. 253-260). Routledge. 
Skifter Andersen, Hans, Andersson, Roger, Wessel, Terje \& Vilkama, Katja (2015). The impact of housing policies and housing markets on ethnic spatial segregation: comparing the capital cities of four Nordic welfare states. International Journal of Housing Policy.

Statistics Finland (2020a). Statistical databases $>>$ StatFin $>>$ Housing $>>$ Rents of dwellings $>$ http:// pxnet2.stat.fi/PXWeb/pxweb/en/StatFin/StatFin__asu__asvu/statfin_asvu_pxt_11x4.x/

Statistics Finland (2020b). Statistical databases $>>$ StatFin $>>$ Housing $>>$ Prices of dwellings in housing companies. http://pxnet2.stat.fi/PXWeb/pxweb/en/StatFin/StatFin__asu__ashi/

Stjernberg, M. (2017): Helsingin seudun 1960- ja 1970-lukujen lähiöiden sosioekonominen ja demografinen kehitys vuoden 1990 jälkeen [The socioeconomic and demographic development of the suburban housing estates of 1960's and 1970's in the Helsinki Region]. Research series 2017:1, City of Helsinki, Executive Office, Urban Research and statistics.

Strandell, A. (2017). Asukasbarometri 2016 - Kysely kaupunkimaisista asuinympäristöistä. Suomen ympäristökeskuksen raportteja 19/2017. Available at https://helda.helsinki.fi/handle/10138/193009.

Tavi, T. (2019): Myllypuron koulutus- ja tulotaso 2000-luvulla - myönteistä mutta epätasaista kehitystä. Kvartti/Helsinki Quarterly 4/2019.

Suomen virallinen tilasto SVT (2018). Asunnot ja asuinolot, Yleiskatsaus 2017.http://www.stat.fi/til/asas/ 2017/01/asas_2017_01_2018-10-10_tie_002_fi.html.

The Social Insurance Institution of Finland (2020) (KELA). Statistical Database. https://www.kela.fi/kelasto

Tilastokatsaus 2019. Asumistukimenot uuteen ennätykseen vuonna 2018. Tilastokatsaus 4/2019.

Tranøy, B. S., Stamsø, M. A., \& Hjertaker, I. (2020). Equality as a driver of inequality? Universalistic welfare, generalised creditworthiness and financialised housing markets. West European Politics, 43(2), $390-411$.

Vaattovaara, M.; A. Joutsiniemi; M. Kortteinen; M. Stjernberg; T. Kemppainen (2018). Experience of a Preventive Experiment: Spatial Social Mixing in Post-World War II Housing Estates in Helsinki, Finland. In Hess, D. B.; T. Tammaru; M. van Ham (Eds.) Housing Estates in Europe. Poverty, Ethnic Segregation and Policy Challenges, 215-240. Springer Open.

van Ham, Maarten \& Tammaru, Tiit (2016): Increasing Socio-Economic Segregation in European Cities. Urbanisation, mobilities and immigration (URMI) Policy Brief, November 2016.

Van Ham, M. \& T. Tammaru (2016) Increasing Socio-Economic Segregation in European Cities. Urbanisation, mobilities and immigration (URMI) Policy Brief, November 2016.

Wyly, E. \& J. Hammel (2001) Gentrification, housing policy, and the new context of urban redevelopment, In: Gotham, K F (eds.) Critical Perspectives on Urban Redevelopment. Research in Urban Sociology,6: 211-276.

Publisher's Note Springer Nature remains neutral with regard to jurisdictional claims in published maps and institutional affiliations. 